\title{
The relationship between paediatric foot posture and body mass - do heavier kids really have flatter feet?
}

Angela Evans ${ }^{1,2}$

From Australasian Podiatry Council Conference 2013

Sydney, Australia. 2-5 June 2013

\section{Background}

The prevailing opinion is that heavier children have flatter feet, a consistent finding of the studies that have addressed this issue. Recently, we queried this observation and postulated that the method of foot posture assessment may influence this finding, as there was no positive relationship between the BMI and FPI- 6 scores of 140 school children. Most other studies have used footprint-based measures.

\section{Methods}

Data was acquired from four datasets from previous works, (South Australia, $n=303$; UK, $n=225$; rural South Australia, $\mathrm{n}=140$; New Zealand, $\mathrm{n}=30$ ) providing 698 observations of children's BMI and FPI- 6 scores. Descriptive statistics were used to examine the basic anthropometrical characteristics of the study populations. Parametric statistical correlations were applied to continuous data, and scatter plots were used to explore and illustrate relationships between parameters.

\section{Results}

The total population results yielded the following mean (SD): age 9.20 years (2.34), BMI $18.29 \mathrm{~kg} / \mathrm{m}^{2}$ (3.52), FPI-6 $4.68-4.95$ (3.12 - 3.31). Gender $\mathrm{N}=698$; 359M: 339F. Correlations between BMI and FPI-6 ranged from -0.89 $(\mathrm{p}=0.05)$ to $-0.115(\mathrm{p}=0.01)$ for the study population $(\mathrm{n}=$ $698)$ aged from 3 to 15 years. The mean population $(\mathrm{n}=698) \mathrm{BMI}=18.29 \mathrm{~kg} / \mathrm{m}^{2}(3.51)$, whereas the mean BMI for the 'flatfoot' (FPI-6 $\geq 6, \mathrm{n}=267)=18.16 \mathrm{~kg} / \mathrm{m}^{2}$

\footnotetext{
Correspondence: a.evans@aut.ac.nz

${ }^{1}$ Health, Rehabilitation and Research Institute, AUT University, Auckland, New Zealand

Full list of author information is available at the end of the article
}

(3.73) and the 'non flat-foot' group BMI (FPI- $6<6$, $\mathrm{n}=431)=18.51(3.43)$.

Using the international obesity task force cut-off points for overweight, the study population was also evaluated for BMI/foot posture (FPI-6) for each age year group.

\section{Conclusion}

This study supports our earlier findings, and conflicts with many other studies, in not finding a positive correlation between increased BMI and 'flatter' feet in children. Clinically, these findings question the need for concern about children's BMI as a specific influence on (flatter) foot posture, and also the validity of footprint based measures.

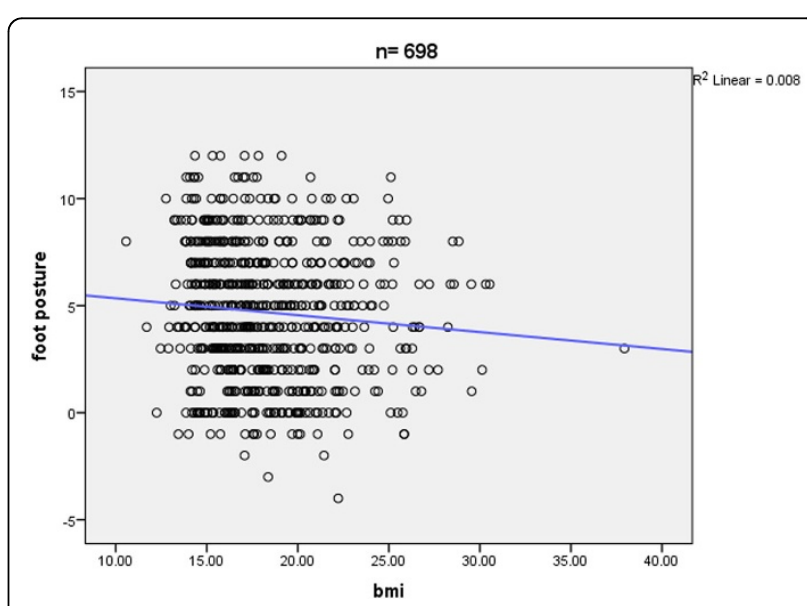

Figure 1 Foot posture versus body mass index. 


\section{Acknowledgement}

Ian Mathieson, Rolf Scharbillig for sharing datasets.

\section{Author details}

'Health, Rehabilitation and Research Institute, AUT University, Auckland, New

Zealand. ${ }^{2}$ Health Science, University of South Australia, Adelaide, 5000,

Australia.

Published: 31 May 2013

doi:10.1186/1757-1146-6-S1-012

Cite this article as: Evans: The relationship between paediatric foot posture and body mass - do heavier kids really have flatter feet?

Journal of Foot and Ankle Research 2013 6(Suppl 1):012.

Submit your next manuscript to BioMed Central and take full advantage of:

- Convenient online submission

- Thorough peer review

- No space constraints or color figure charges

- Immediate publication on acceptance

- Inclusion in PubMed, CAS, Scopus and Google Scholar

- Research which is freely available for redistribution

Submit your manuscript at www.biomedcentral.com/submit 